\title{
Immunochemical method for detection of albumin in human meconium
}

\author{
F. E. BULL, D. E. O. GLADWIN, and A. D. GRIFFITHS \\ From the Departments of Clinical Chemistry and Paediatrics, Nevill Hall Hospital, Abergavenny, \\ Monmouthshire
}

\begin{abstract}
Bull, F. E., Gladwin, D. E. O., and Griffiths, A. D. (1974). Archives of Disease in Childhood, 49, 602. Immunochemical method for detection of albumin in human meconium. A simple immunochemical technique utilizing single radial immunodiffusion for the demonstration of albumin in human meconium is described. A comparison of this technique with the more widely used sulphosalicylic acid precipitation method is reported. We also have attempted to determine the normal levels of albumin in meconium.
\end{abstract}

A raised protein level in the meconium of an infant with cystic fibrosis (CF) was described by Buchanan and Rapoport (1952) in an infant with meconium ileus. The work of Green, Clarke, and Shwachman (1958) confirmed this finding and showed that the protein was predominantly albumin. Wiser and Beier (1964) and Green and Shwachman (1968) subsequently showed that the meconium of infants with CF contained high levels of protein even in the absence of meconium ileus, and this has since been confirmed by many other workers.

Estimation of the protein content of meconium was suggested as a possible screening procedure for CF by Schutt and Isles (1968). A preliminary report of an infant with CF detected by such a procedure was published by Cain, Deall, and Noble (1972). In late 1971, this hospital, as part of a larger study, started to screen the newborn of North Monmouthshire and Breconshire for CF, using the meconium protein technique. The method of protein detection suggested by the organizers of the survey (R. Prosser, personal communication, 1971) was the sulphosalicylic acid (SSA) precipitation technique. At an early stage in the study it became evident that the detection of a white precipitate at the junction of a dark green fluid and a colourless liquid was extremely difficult, except in the presence of large amounts of protein, and it was decided to develop an immunochemical technique for the detection of albumin in meconium.

Received 1 February 1974.

\section{Technique}

$1 \mathrm{~g}$ well-mixed meconium was extracted within 24 to 48 hours of collection with $4 \mathrm{ml}$ of $0.85 \%$ (w/v) saline on a rollermixer ${ }^{\star}$ for 2 hours. The resultant extract was centrifuged at 2500 r.p.m. for 5 to 10 minutes giving a clear deep green supernatant which was considered to be a 1/5 dilution of the original meconium. Standard albumin solutions were prepared by diluting a stock 30 $\mathrm{g} / 100 \mathrm{ml}$ albumin solutiont to give a range of 5 to 50 $\mathrm{mg} / 100 \mathrm{ml}$ in saline.

Antialbumin plates were prepared as follows. $0.2 \mathrm{ml}$ antihuman albumin serum $\ddagger$ in $6 \mathrm{ml}$ of $0.85 \%(\mathrm{w} / \mathrm{v})$ saline at $50^{\circ} \mathrm{C}$ was mixed with $6 \mathrm{ml}$ of $2 \%$ (w/v) Ionagar No. $2 \$$ in $0.85 \%(\mathrm{w} / \mathrm{v})$ saline at $50^{\circ} \mathrm{C}$ and was poured into an $8.5 \mathrm{~cm}$ petri dish. $2 \mathrm{~mm}$ wells, $1 \mathrm{~cm}$ apart, were punched in the agar. One plate will take 30 to 50 tests. A fixed volume $(5 \mu 1)$ of albumin standards and meconium extracts were placed in the wells and the plates incubated in a moist chamber at room temperature for 20 hours. The diameter of the precipitin rings was read to the nearest $0.1 \mathrm{~mm}$.

For the SSA technique, doubling dilutions of meconium extracts were made in $0.85 \%(\mathrm{w} / \mathrm{v})$ saline from $1 / 10$ to $1 / 1280$ in precipitin tubes. $3 \%$ SSA was layered on the surface of the diluted extract (as suggested by R. Prosser, personal communication, 1971). The formation of a white precipitate at the junctions of the two liquids indicated the presence of protein in the meconium. This technique will detect normal serum protein to a dilution of $1 / 1000$.

^Luckham Ltd., Labro Works, Burgess Hill, Sussex.

†Calbiochem Ltd., 10 Wyndham Place, London W1H 1AS.

$\ddagger$ Behringwerke Ltd., Hoechst Pharmaceuticals, Brentford, Middx.

§Oxoid Ltd., Southwark Bridge Road, London SE1 9HF. 


\section{Results}

Fig. 1. shows the linear relation between log albumin concentration and precipitin ring diameter.

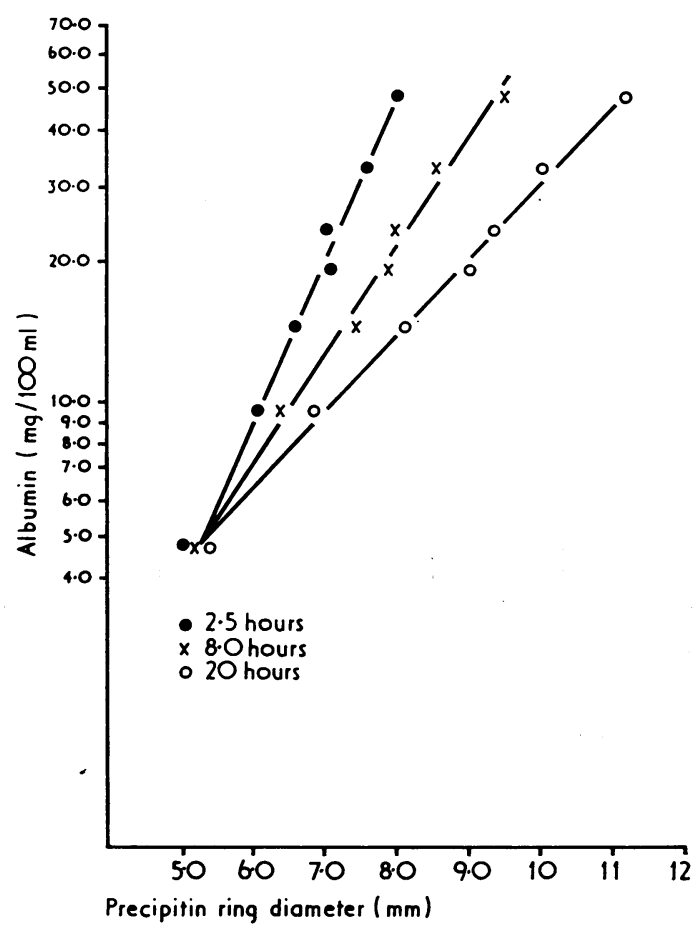

FIG. 1.-Linear relation between log albumin concentration and precipitin ring diameter at room temperature over timed intervals.

Greatest sensitivity was obtained if the plate was allowed to incubate for 20 hours. In routine practice the plates are left to develop overnight.

420 samples were analysed during the initial study and the range of albumin concentrations found in the $1 / 5$ meconium extracts are illustrated in Fig. 2. It is apparent that with four exceptions the albumin concentration of the meconium samples was below $20 \mathrm{mg} / 100 \mathrm{ml}$ in the $1 / 5$ extract, and the majority were below $10 \mathrm{mg} / 100 \mathrm{ml}$. The three samples with albumin values of 40,51 , and $155 \mathrm{mg} / 100 \mathrm{ml}$ were positive for occult blood. These samples cannot, therefore, be considered normal and were excluded from the study, though the infants from whom they were obtained were followed up to exclude CF (see Discussion).

It was decided initially to accept a concentration of $20 \mathrm{mg} / 100 \mathrm{ml}$ in the $1 / 5$ extract as the upper limit of albumin in normal meconium. For the purposes of the screening survey using the SSA test, a titre of
$1 / 64$ or greater was accepted as a positive result (R. Prosser, personal communication, 1971). Because of the differences in the initial dilution factor for the immunochemical technique, it was decided to accept a titre of $1 / 40$ or greater as a positive result.

399 samples were examined by both methods and a comparison of these results is illustrated in Fig. 3. It is evident from these results that values of 20 $\mathrm{mg} / 100 \mathrm{ml}$ or lower in the $1 / 5$ extract are similar to an SSA titre of $1 / 20$ or lower and well within the limits of normality set for the SSA technique.

\section{Discussion}

The work reported in this paper is part of a more general survey of the newborn of Monmouthshire and Breconshire for CF using meconium protein as the screening test. The SSA test was chosen to measure the meconium protein concentrations by the organizers of the survey. However, we came to the conclusion that this test was not easy to perform satisfactorily, and developed the immunochemical assay for albumin to replace it in our area.

The 3 infants with meconium albumin values of 40,50 , and $155 \mathrm{mg} / 100 \mathrm{ml}$ (SSA titre of $1 / 80,1 / 160$, and $1 / 320$, respectively) who were excluded from the study were followed up clinically to exclude CF. They were found to have normal sweat tests and no clinical evidence of CF. Meconium samples with albumin levels of $20 \mathrm{mg} / 100 \mathrm{ml}$ and greater are routinely checked for occult blood.

False positive results occurred in only 3 of the 420 cases studied. These were infants whose meconium albumin levels were greater than $20 \mathrm{mg} / 100 \mathrm{ml}$, but who were later shown not to have CF. This represents a false positive rate of less than $1 \%$ and all 3 cases were explained by the presence of occult blood.

Subsequently, the infant with the meconium protein concentration of $20 \mathrm{mg} / 100 \mathrm{ml}$ was shown to have CF. This infant was born at term after an uneventful pregnancy, birthweight $2 \cdot 44 \mathrm{~kg}$. She was the youngest of 3 children, the second of whom was known to have CF. The meconium protein estimation was well within the normal range for the SSA method, at a titre of $1 / 16$. At the age of 16 days she developed a cough and intermittent cyanosis and examination revealed signs of a chest infection which was confirmed radiologically. A skin chloride estimation at this time was normal at $32 \mathrm{mEq} / \mathrm{l}$. Subsequent progress was uneventful until the age of 13 months when her weight gain fell from the 25 th to the 3 rd centile line. She became grizzly and her stools were frequent, containing undigested food, but were formed and not offensive. A 3-day faecal fat excretion was normal at $0.8 \mathrm{~g} /$ day 


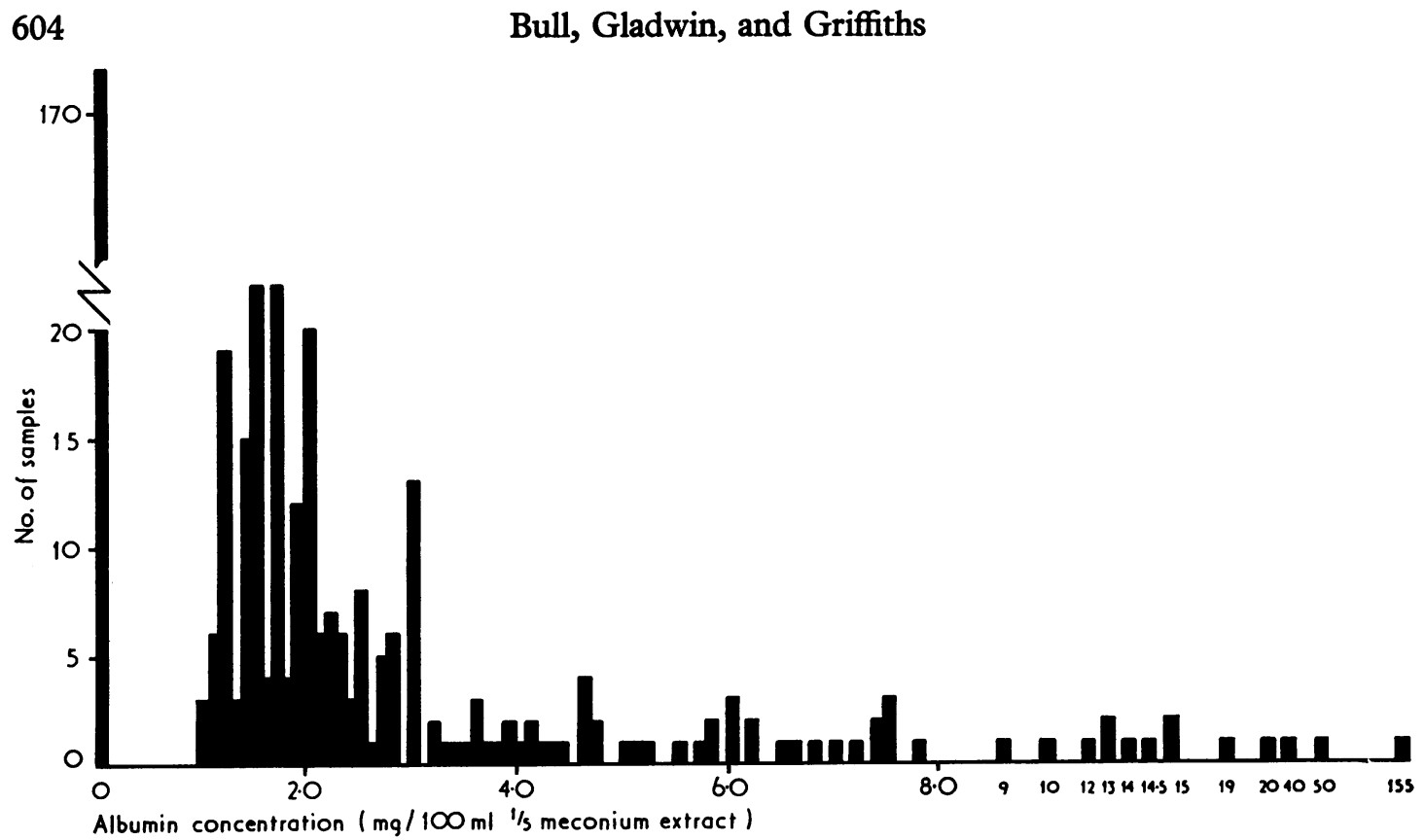

FIG. 2.-Range of albumin concentrations found in the 1/5 extract of the 420 meconium samples tested by the immunochemical technique.

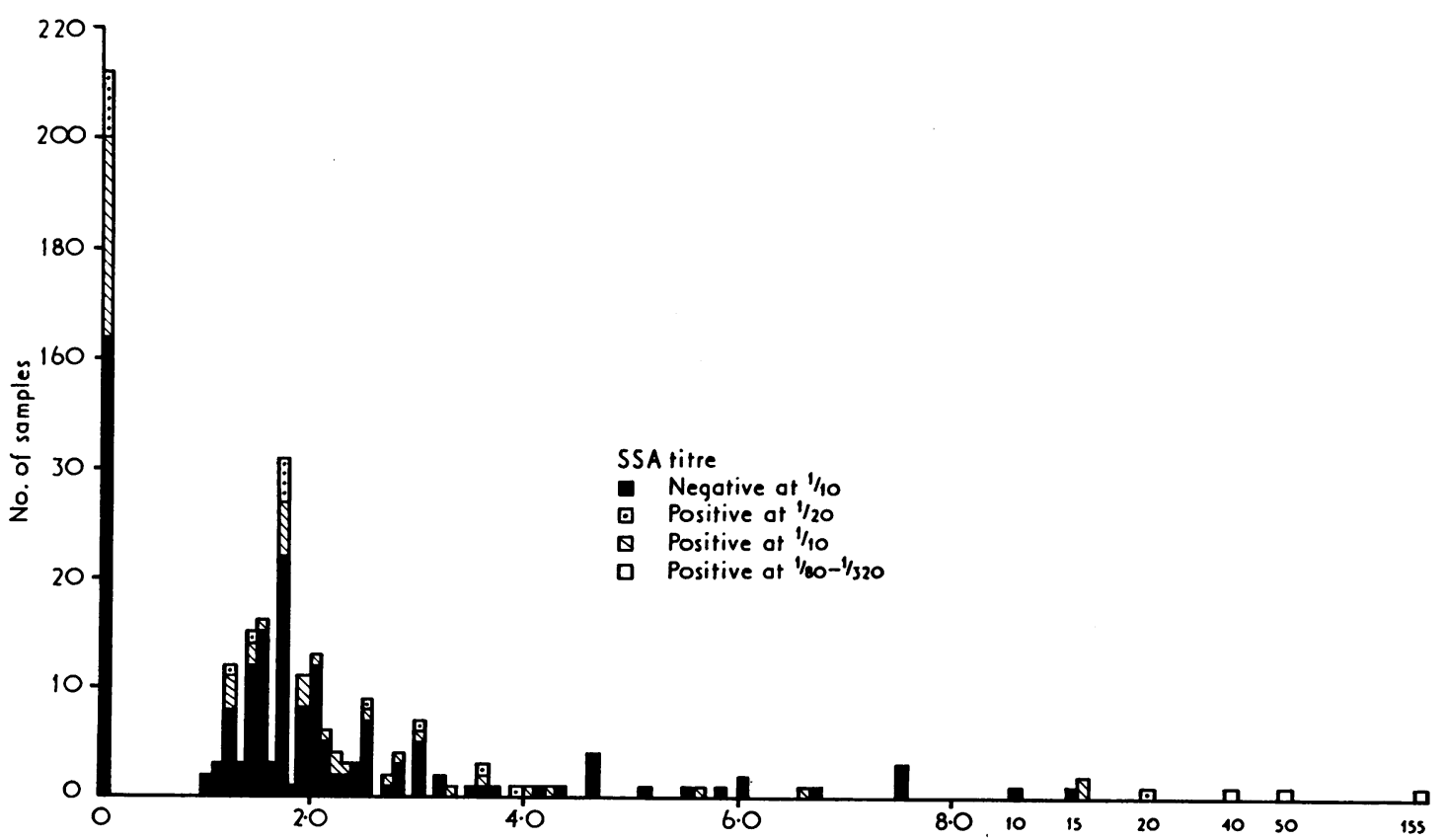

Albumin concentration ( $\mathrm{mg} / 100 \mathrm{ml} 1 / \mathrm{s}$ meconium extract)

FIG. 3. - Comparison of albumin concentrations in the $1 ! 5$ meconium extracts by the immunochemical technique with the $S S A$ titre for 399 samples tested by both methods. 
(as stearic acid), and the bone age at the wrist was approximately 12 months. A repeat sweat test, however, was suggestive of CF: weight of sweat 97 $\mathrm{mg}, \mathrm{Na}+73 \mathrm{mEq} / \mathrm{l}$., $\mathrm{Cl}-99 \mathrm{mEq} / \mathrm{l}$.

Over the next few months she remained miserable, with abnormal stools and respiratory infections, and at the age of 16 months treatment was started with pancreatic extract and routine ampicillin and cloxacillin. After this her stools became less frequent and weight gain improved. A further sweat test at 20 months was diagnostic of $\mathrm{CF}$ : weight of sweat $254 \mathrm{mg}, \mathrm{Na}+93 \mathrm{mEq} / 1 ., \mathrm{Cl}-106$ $\mathrm{mEq} / \mathrm{l}$., skin chloride $95 \mathrm{mEq} / \mathrm{l}$.

We now accept values of less than $20 \mathrm{mg} / 100 \mathrm{ml}$ meconium extract as normal and routinely check all infants with values of $20 \mathrm{mg} / 100 \mathrm{ml}$ and greater.

During the 2 years that the survey has been in progress a total of 4800 meconiums have been examined for protein by the immunochemical technique and of these, 24 have had values of 20 $\mathrm{mg} / 100 \mathrm{ml}$ and greater; 18 of the patients have been examined clinically and had adequate sweat tests performed and, with the exception of the case reported above, have been found to be free of CF. Of the remaining 6,1 is being followed up in another area and is so far normal, another is clinically normal but we have consistently failed to obtain sufficient sweat for analysis, while the remaining 4 have consistently defaulted at their follow-up appointments despite home visits by the health visitor. This represents a maximum false positive rate of $0.5 \%$ which is acceptable to the paediatricians. No false negative results have occurred to date, but with experience it may be necessary to lower the upper limit of albumin concentration which is now considered normal.

While the above investigation was in progress, Kollberg and Hellsing (1972) reported that meconium albumin levels of greater than $20 \mathrm{mg} / \mathrm{g}$ dried meconium were of significance in the detection of CF. In absolute terms the present method takes a level of $4 \mathrm{mg} / \mathrm{g}$ dried meconium as significant, since the solid content of meconium averages $24.5 \%$ (average of 10 analyses), hence the present technique is more sensitive.

We suggest that the immunochemical test is simpler to perform and control than the SSA technique for the detection of albumin in meconium. The cost is approximately 6.5 pence per testreagents and materials only-and is less time consuming than the SSA technique. In practice it is only necessary to put up the $20 \mathrm{mg} / 100 \mathrm{ml}$ standard and compare the test diameters with this. All infants with values of $20 \mathrm{mg} / 100 \mathrm{ml}$ or greater are followed up clinically and a sweat test is carried out. The immunochemical test for albumin in meconium is well suited to a screening programme for $\mathrm{CF}$ in the newborn.

We thank the North Monmouthshire Hospital Management Committee for facilities to carry out this work; the midwives of the hospital and District Maternity Services for the collection of specimens; $\mathrm{Mr}$. P. Dykes for the sweat test analysis; Mr. D. Lomax for illustrations; and Miss L. Jones and Mrs. E. Stacey.

\section{REFERENCES}

Buchanan, D. J., and Rapoport, S. (1952). Chemical comparison of normal meconium and meconium from a patient with meconium ileus. Pediatrics, 8, 304.

Cain, A. R. R., Deall, A. M., and Noble, T. C. (1972). Screening for cystic fibrosis by testing meconium for albumin. Archives of Disease in Childhood, 47, 131.

Green, M. N., Clarke, J. T., and Shwachman, H. (1958). Studies in cystic fibrosis of the pancreas: protein pattern in meconium ileus. Pediatrics, 21, 635.

Green, M. N., and Shwachman, H. (1968). Presumptive tests for cystic fibrosis based on serum protein in meconium. Pediatrics, 41, 989.

Kollberg, H., and Hellsing, K. (1972). Screening for cystic fibrosis. Archives of Disease in Childhood, 47, 836.

Schutt, W. H., and Isles, T. E. (1968). Protein in meconium from meconium ileus. Archives of Disease in Childhood, 43, 178.

Wiser, W. C., and Beier, F. R. (1964). Albumin in the meconium of infants with cystic fibrosis. A preliminary report. Pediatrics, 33, 115.

Correspondence to Mr. F. E. Bull, Department of Pathology, Nevill Hall Hospital, Abergavenny, Mon. 